\title{
Integrasi Kurikulum Internasional, Nasional Dan Madrasah Untuk Meningkatkan Kualitas Lulusan Di Mi Muslimat Nu Pucang Sidoarjo
}

\author{
Solichati ${ }^{1)}$, \\ Musfiqon*, 2) \\ ${ }^{1}$ Program Studi Magister Manajemen Pendidikan Islam, Fakultas Agama Islam, Universitas Muhammadiyah \\ Sidoarjo, Indonesia, Jl. Mojopahit 666bSidoarjo, Indonesia \\ ${ }^{2}$ Program Studi Magister Manajemen Pendidikan Islam, Fakultas Agama Islam, Universitas Muhammadiyah \\ Sidoarjo, Indonesia, Jl. Mojopahit 666 b Sidoarjo, Indonesia
}

\author{
solichati.fai@umsida.ac.id ${ }^{1)}$, \\ musfiqon@umsida.ac.id ${ }^{2}$
}

\begin{abstract}
The research has purpose to know the implementation of integration the international, national, and madrasah curriculum in MI Muslimat NU Pucang Sidoarjo. The policies carried out by the head of madrasah through preparation of RKM, fulfillment of eight SNPs, division of job discribtion, providing guidance to educators and education staff in conducting supervision that programmed well. The implementation of integrating of third curriculum carried out by adopting Mathematic, English and Science subjects from the Cambridge University international curriculum and adapting general subjects from the national curriculum 2018 revision of the Ministry of Education and Culture and religious subjects al-Qur'an Hadith, Aqidah akhlaq, Fiqh, SKI and Arabic madrasah curriculum from the Ministry of Religion through the development the forms of learning processing and classroom, Development of the PAIKEM learning model, self-development program and evaluation. The quality of graduates after the implementation of integration the international, national and madrasah curriculum in MI Muslimat NU Pucang Sidoarjo accepted in the favorite of SMP/MTS which are evidenced with the results of SKHUN, UN, UAMBD and Check Point. The result of the research show that integration of international, national, and madrasah curriculum has been running as it should.
\end{abstract}

Keywords-Integration, International Curriculum, National Curriculum, Madrasah Curriculum, Graduates Quality

\section{PENDAHULUAN}

Madrasah ibtida'iyah sebuah institusi di bawah KEMENAG (Kementerian Agama) yang dipandang sebelah mata oleh sebagian besar orang, dimarginalkan dan menjadi pilihan terakhir oleh orang tua peserta didik. Anggapan orang bahwa lulusan madrasah ibtida'iyah masih kalah dengan lulusan sekolah dasar di bawah naungan Kementerian Pendidikan dan Kebudayaan. Sudah terdengar dan di jumpai sedikit sekali madrasah ibtida'iyah yang eksis, jika diibaratkan dengan pribahasa madrasah hidup enggan mati tidak mau. Apalagi dengan munculnya persaingan di Sekolah Dasar gratis SPP karena adanya Bantuan Operasional Sekolah (BOS). Hal ini sejalan tujuan pendidikan Islam seringkali diarahkan untuk menghasilkan manusia-manusia yang hanya menguasai bidang keilmuan Islam saja dan visinya diarahkan untuk mewujudkan manusia yang shalih dalam arti taat beribadah dan gemar beramal untuk tujuan akhirat. Akibatnya, lulusan pendidikan Islam hanya memiliki kesempatan dan peluang yang terbatas yaitu hanya sebagai pengawal moral bangsa. Output dari pendidikan Islam semakin termaginalkan dan tak berdaya menghadapi persaingan yang semakin kompetitif di era globalisasi (Andi Septilinda Susiyani, 2017). Para pakar pendidikan menyadari perlu dilakukan inovasi dalam sistem pendidikan secara keseluruhan, dari dimensi basis filosofi pendidikan sampai dimensi instrumental berupa kurikulum, sistem pembelajaran dan strategi serta metode dalam proses pembelajaran dalam suatu lembaga pendidikan. Konsep inovasi ini bertujuan agar terjadi perubahan pada kualitas pendidikan yang terdapat dalam al Qur'an surat ar Ra'd ayat 11 berbunyi:" Bagi manusia ada malaikat-malaikat yang selalu mengikutinya bergiliran, di muka dan di belakangnya, mereka menjaganya atas perintah Allah. Sesungguhnya Allah tidak merobah Keadaan sesuatu kaum sehingga mereka merobah keadaan yang ada pada diri mereka sendiri. dan apabila Allah menghendaki keburukan terhadap sesuatu kaum, Maka tak ada yang dapat menolaknya; dan sekali-kali tak ada pelindung bagi mereka selain Dia”. Ayat ini memiliki kandungan bahwa untuk merubah suatu kondisi atau keadaan harus ada usaha atau inovasi. Inovasi dalam pendidikan ini dilakukan sebagai upaya untuk peningkatan kualitas pendidikan yang ada di Indonesia melalui pengenalan penemuan cara baru dalam sistem pendidikan berbarengan dengan adaptasi kultur pendidikan yang ada di Indonesia (benchmarking)(Supriyanto, 2009). Inovasi pendidikan dilakukan dalam proses pengembangan kurikulum yang dapat merespon terhadap tuntutan perubahan perkembangan ilmu dan 
teknologi maupun globalisasi. Kebijakan kurikulum dalam pengembangan kurikulum harus sejalan dengan visi, misi dan strategi pembangunan pendidikan nasional yang dituangkan dalam kebijakan peningkatan angka partisipasi, mutu, relevansi, dan efesiensi pendidikan. Untuk dapat bersaing dan meraih sukses salah satunya dengan mewujudkan masyarakat yang berkualitas sehingga mempersiapkan peserta didik menjadi subyek yang berperan menampilkan keunggulan dirinya yang tangguh, kreatif, mandiri, dan profesional dalam bidangnya masing-masing (Mulyana, 2006). Cara untuk mewujudkan tujuan masyarakat yang berkualitas melalui penerapan integrasi kurikulum internasional, nasional dan madrasah untuk meningkatkan kualitas lulusan dari suatu lembaga pendidikan.

\section{A. Integrasi Kurikulum}

Kurikulum ditinjau dari asal katanya dari bahasa Yunani yang mula-mula dalam bidang olah raga, yaitu kata Currere yang berarti jarak tempuh(Subandijah, 1996). Dalam bahasa Arab istilah kurikulum diartikan dengan Minhaj, yakni jalan yang terang yang dilalui oleh manusia dalam kehidupannya(Muhajirin, 2007). Kemudian, pengertian tersebut diterapkan dalam dunia pendidikan menjadi sejumlah mata pelajaran (subject) yang harus ditempuh oleh seorang siswa dari awal sampai akhir program pelajaran untuk memperoleh ijazah(Herry, 2011). Pengertian kurikulum tersebut mengandung dua pokok yaitu: (1) Adanya mata pelajaran yang harus ditempuh oleh peserta didik dan, (2) Tujuan utamannya yaitu untuk memperoleh ijazah. Kurikulum tidak terbatas hanya pada sejumlah mata pelajaran saja, tetapi mencakup semua pengalaman belajar (learning experiences) yang dialami peserta didik dan mempengaruhi perkembangan pribadinya. Dari beberapa teoritis dapat disimpulkan bahwa kurikulum bukanlah. sesuatu yang tunggal, tetapi kurikulum mempunyai empat dimensi pengertian yang saling berhubungan dengan satu dan yang lainnya. Keempat dimensi kurikulum tersebut yaitu: (1) Kurikulum sebagai suatu ide, (2) Kurikulum sebagai suatu rencana tertulis yang sebenarnya merupakan perwujudan dari kurikulum sebagai suatu ide, (3) Kurikulum sebagai suatu kegiatan yang sering disebut dengan istilah kurikulum sebagai suatu realita atau implementasi kurikulum, (4) Kurikulum sebagai suatu hasil yang merupakan konsekuensi dari kurikulum sebagai suatu kegiatan. Kurikulum dalam suatu satuan pendidikan dapat terlaksana dengan baik jika antara isi, tujuan dan bahan dalam kurikulum yang disusun oleh satuan pendidikan tersebut dapat memenuhi kebutuhan dari masyarakat. Maka, satuan pendidikan harus dapat merancang kurikulum yang sesuai dengan kebutuhan masyarakat di satuan pendidikan tersebut.

Kata "integrasi" menurut KBBI. In॰teg•ra•si n pembauran hingga menjadi kesatuan yang utuh atau bulat. Integrated curriculum didefinisikan sebagai“....As a way to teach students that attempts to break down barriers between subject sand make learning more meaningful to students. The idea is to teach around theme ,or "organizing centers" that students can identify with, such as" the Environment,"'Life in School, "or "more traditional are as like "My thousand Legends"(Geogle, 2016). Integrasi kurikulum merupakan cara untuk mengajar peserta didik yang meniadakan batasan antara mata pelajaran dan membuat belajara lebih bermakna. Ide ini adalah untuk mengajarkan yang ada di sekitar dan memusatkan yang ada di lingkungan sekolah. Maka dapat disimpulkan bahwa integrasi kurikulum dapat diterjemahkan dengan kombinasi kurikulum yaitu penggabungan kurikulum dengan mengadopsi tiga mata pelajaran Mathematic, Science dan English dari kurikulum internasional Cambridge University, diadaptifkan dengan kurikulum nasional Kementerian Pendidikan dan Kebudayaan yaitu kurtilas revisi 2018 dan kurikulum madrasah yaitu Kementerian Agama yang memuat bidang Pendidikan Agama Islam (PAI) meliputi Qur'an Hadits, Aqidah akhlak, Fiqih, SKI, dan Bahasa Arab yang representative mewakili visi, misi dan tujuan yang ingin dicapai dalam lembaga pendidikan dengan menggunakan proses pembelajaran yang mengarahkan peserta didik menjadi manusia yang selalu berinteraksi dengan alam dan lingkungannya sesuai dengan potensinya masing-masing.

\section{B. Kurikulum Internasional}

Lembaga pendidikan yang menerapkan kurikulum internasional berpedoman pada SNP yang diperkaya dengan SNP negara maju. Kurikulum internasional yaitu kurikulum yang diadaptasi dari kurikulum University Of Cambridge yang mengembangkan pemahaman, pengetahuan dan keterampilan perserta didik yang merupakan inti dari pengalaman belajar. Program yang menaungi kurikulum Cambridge yaitu Cambridge International Examinations. Cambridge International Examinations adalah salah satu program pendidikan internasional dan kualifikasi anak berusia 5-19 tahun(CIE, 2018). Misi dari Cambridge International Examinations adalah untuk memberikan pendidikan yang unggul dalam kelas dunia melalui penyediaan kurikulum, penilaian dan jasa. 
Berikut adalah dasar- dasar penerapan kurikulum Cambridge yaitu: (1) Merupakan penyedia program dan kurikulum pendidikan internasional terbesar di dunia selama 19 tahun, (2) Merupakan lembaga nirlaba dan bagian dari Universitas Cambridge, salah satu universitas terbaik dan terpercaya di dunia, (3) Standard kurikulum telah diakui oleh berbagai universitas dan perusahaan top dunia, (4) Meningkatkan pengetahuan dan keterampilan peserta didik, agar kelak berguna di masyarakat, (5) Mengembangkan pola pikir siswa didalam dan diluar sekolah. Adapun tujuan penerapan kurikulum Cambridge yaitu (1) Untuk memberikan pendidikan yang unggul dalam kelas dunia melalui penyediaan kurikulum, penilaian dan jasa, (2) Berkomitmen untuk memperluas akses pendidikan yang berkualitas tinggi kepada peserta didik diseluruh dunia.

Program pendidikan Cambridge terdiri dari empat kualifikasi, yaitu (1) Cambridge International Primary Program (CIPP): 5-11 tahun. Mempelajari bidang akademis bahasa Inggris, matematika, dan sains, (2) Lower Secondary Program: 11-14 tahun. Meneruskan bidang pembelajaran dari pelajaran dasar (bahasa Inggris, matematika, dan sains), dan ditambah dengan mempersiapkan anak untuk menempuh IGCSE atau O Level, (3) Middle Secondary: 14-16 tahun Tahap ini terkenal dengan kurikulum International General Certificate of Secondary Education (IGCSE) atau O level. Kualifikasi O level terutama dirancang untuk peserta didik yang bahasa utamanya bukan bahasa Inggris. Siswa dapat memilih mata pelajaran yang diminati dalam persiapan menuju A level serta membekali kemampuan untuk bekerja nantinya, (4) Upper Secondary: 16-18 tahun. Kualifikasi Internasional A level, diperlukan untuk melanjutkan pendidikan ke universitas di seluruh dunia. Pada tahap ini siswa bebas memilih mata pelajaran yang diminati sesuai kemampuan mereka.

\section{Kurikulum Nasional}

Kurikulum nasional saat ini adalah kurikulum 2013 yang implementasinya dilakukan serempak tahun 2014 pada seluruh sekolah di lingkungan pendidikan dasar dan menengah, memposisikan guru memegang perranan penting terutama merealilsasikan pembelajaran(Mulyasa, 2016). Implementasi kurikulum 2013 yang berbasis karakter dan kompetensi memerankan guru sebagai pembentuk karakter dan kompetensi peserta didik, yang kreatif dalam memilih dan memilah, serta mengembangkan metode dan materi pembelajaran.

Kurikulum 2013 dikembangkan dengan penyempurnaan pola pikir sebagai berikut:

(1) Penguatan pola pembelajaran yang berpusat pada peserta didik,

(2) Penguatan pola pembelajaran interaktif (interaktif guru- peserta didik-masyarakat-lingkungan alam, sumber/media lainnya),

(3) Penguatan pola pembelajaran secara jejaring (peserta didik dapat menimba ilmu dari siapa saja dan dari mana saja yang dapat dihubungi serta diperoleh melalui internet),

(3) Penguatan pembelajaran aktif-mencari (pembelajaran siswa aktif mencari semakin diperkuat dengan pendekatan pembelajaran saintifik),

(4) Penguatan pola belajar sendiri dan kelompok (berbasis tim),

(5) Penguatan pembelajaran berbasis multimedia,

(6) Penguatan pola pembelajaran berbasis klasikal-massal dengan tetap memperhatikan pengembangan potensi khusus yang dimiliki setiap peserta didik,

(7) Penguatan pola pembelajaran ilmu pengetahuan jamak (multidisciplines); dan (

(8) Penguatan pola pembelajaran kritis. Kurikulum 2013 dilakukan penguatan tata kelola sebagai berikut: (1) Penguatan tata kerja guru lebih bersifat kolaboratif, (2) Penguatan manajeman sekolah melalui penguatan kemampuan manajemen kepala sekolah sebagai pimpinan kependidikan (educational leader); dan (3) Penguatan sarana dan prasarana untuk kepentingan manajemen dan proses pembelajaran.

Kurikulum 2013 atau kurtilas yang merupakan kurikulum nasional MI Muslimat NU Pucang Sidoarjo diintegrasikan dengan dua program pemerintah yaitu Penguatan Pendidikan Karakter (PPK) dan Gerakan Literasi Sekolah (GLS) atau yang biasa disebut dengan budaya literasi dengan tujuan dapat meningkatkan kompetensi guru dalam bidang literasi. Selain itu kurikulum ini juga melatih keterampilan abad ke-21 peserta didik dengan cara melatih peserta didik agar bisa berfikir tingkat tinggi melalui Creative thingking, Critical thingking, Collabotarive, HOTS (High Order Thinking Skill) dan Communicativ. Penerapan aspek penilaian Kurikulum 2013 pengetahuan (kognitif), sikap (afektif) dan keterampilan (psikomotor). Penilaian tersebut diambil melalui proses dalam kegiatan pembelajaran yang sedang berlangsung, Daily Test, The First Assessment Holistic (AH1), The Second Assessment Holistic (AH2), The Final Test of The First Semester (PAS) dan The Final Test of The First Semester (PAT) dengan menggunakan soal HOTS (High Order Thinking Skill). 


\section{Kurikulum Madrasah}

Kurikulum Madarasah 2013 Mata Pelajaran Pendidikan Agama Islam dan Bahasa Arab di Madrasah mencakup Kerangka Dasar dan Struktur Kurikulum, Standar Isi, Standar Proses, dan Standar Penilaian Pendidikan Agama Islam dan Bahasa Arab. Kurikulum madrasah 2013 bertujuan untuk mempersiapkan manusia Indonesia agar memiliki kemampuan hidup sebagai pribadi dan warga negara yang beriman, produktif, kreatif, inovatif, dan afektif serta mampu berkontribusi pada kehidupan bermasyarakat, berbangsa, bernegara, dan peradaban dunia.

Kurikulum madrasah 2013 yang diterapkan di MI Muslimat NU Pucang Sidoarjo berdasarkan SK Dirjen Pendidikan Islam Nomor 5114 Tahun 2014 tentang Penetapan Madrasah Pelaksana Kurikulum 2013 dan Lampiran SK Dirjen Nomor 5114 Tahun 2014. Kurikulum madrasah 2013 ini mengembangkan aspek-aspek potensi manusia yang terkait dengan domain sikap untuk pengembangan soft-skills yang seimbang dengan hardskills, seiring dengan ruh Pendidikan Agama Islam itu sendiri.

Kurikulum madrasah 2013 di MI Muslimat NU Pucang Sidoarjo ini dirancang dengan karakteristik sebagai berikut: (1) Mengembangkan keseimbangan antara pengembangan sikap spiritual dan sosial, rasa ingin tahu, kreativitas, kerja sama dengan kemampuan intelektual dan psikomotorik; (2) Madrasah merupakan bagian dari masyarakat yang memberikan pengalaman belajar terencana dimana peserta didik menerapkan apa yang dipelajari di sekolah ke masyarakat dan memanfaatkan masyarakat sebagai sumber belajar; (3) Mengembangkan sikap, pengetahuan, dan keterampilan serta menerapkannya dalam berbagai situasi di madrasah dan masyarakat;

(4) Memberi waktu yang cukup leluasa untuk mengembangkan berbagai sikap, pengetahuan, dan keterampilan;

(5) Kompetensi dinyatakan dalam bentuk kompetensi inti kelas yang dirinci lebih lanjut dalam kompetensi dasar mata pelajaran; (6) Kompetensi inti kelas menjadi unsur pengorganisasian (organizing elements) kompetensi dasar, di mana semua kompetensi dasar dan proses pembelajaran dikembangkan untuk mencapai kompetensi yang dinyatakan dalam kompetensi inti; (7) Kompetensi dasar dikembangkan didasarkan pada prinsip akumulatif, saling memperkuat (reinforced) dan memperkaya (enriched) antar mata pelajaran dan jenjang pendidikan (organisasi horizontal dan vertikal).

\section{E. Kualitas Lulusan}

Arti dasar kata kualitas dalam Kamus Modern Bahasa Indonesia adalah "kualitet”: "mutu, baik buruknya barang(Barry, 2001). Seperti halnya yang dikutip oleh Quraish Shihab yang mengartikan kualitas sebagai tingkat baik buruk sesuatu atau mutu sesuatu (Shihab, 1999). Secara etimologi, mutu atau kualitas diartikan dengan kenaikan tingkatan menuju suatu perbaikan atau kemapanan. Sebab kualitas mengandung makna bobot atau tinggi rendahnya sesuatu. Terdapat tiga konsepsi mutu yang paling populer yang telah dikembangkan oleh tiga pakar mutu tingkat internasional, yaitu W. Edwards Deming, Philip B. Crosby, dan Joseph M. Juran (Yamit, 2001) Menurut Deming mutu adalah apapun yang menjadi kebutuhan dan keinginan pelanggan. Menurut Crosby mutu adalah sebagai kesesuaian terhadap persyaratan. Sedangkan Juran mendefinisikan mutu adalah kesesuaian terhadap spesifikasi.

Deming mendefinisikan mutu sebagai pengembangan yang terus menerus dari suatu sistem yang stabil. Definisi itu menekankan pada dua hal berikut (Sriwidadi, 2001): (1) Semua sistem (administrasi, desain, produksi, dan penjualan) harus stabil, (2) Perbaikan yang terus menerus dari berbagai sistem untuk mengurangi penyimpangan dan lebih memenuhi kebutuhan pelanggan. Ada empat belas prinsip manajemen menurut Deming sebagai berikut: (1) Menciptakan kegunaan yang konstan terhadap perbaikan produk dan jasa, (2) Mengambil filosofi baru dengan menolak kebiasaan penerimaan kesalahan, kerusakan, dan penundaan, (3) Menghilangkan ketergantungan pada inspeksi massal, (4) Meminimumkan biaya total, (5) Perbaikan secara konstan, dan selamanya, sistem produksi untuk memperbaiki mutu dan produktivitas dan secara konstan mengurangi biaya,

(6) Pelatihan pada semua bidang kerja untuk semua karyawan, (7) Menitikberatkan manajemen dan penyelia (supervisor) pada kepemimpinan karyawan untuk membantu mereka melakukan pekerjaan dengan lebih baik,

(8) Menghilangkan ketakutan. Jangan memarahi karyawan untuk masalah sistem, (9) Singkirkan penghalang antar departemen. Kembangkan kerja sama antara area yang berbeda, seperti riset, desain, produksi, dan penjualan, (11) Hilangkan program, desakan, dan slogan yang memerlukan tingkat produksi baru tanpa adanya metode yang lebih baik, (12) Hilangkan kuota, standar kerja, dan tujuan yang berubah-ubah yang berinterferensi dengan mutu, (13) Singkirkan barrier yang menghilangkan kebanggaan karyawan akan pekerjaannya, (14) Kembangkan pendidikan dan perbaikan diri terus menerus dari seluruh karyawan.

Philip B. Crosby dalam bukunya Quallity is Free mengungkapkan empat dalil mutu diantaranya: (1) Definisi mutu adalah kesesuaian dengan persyaratan; (2) Sistem mutu adalah pencegahan; (3) Standar kerja adalah 
Tanpa Cacat (Zero Defect); (4) Pengukuran mutu adalah biaya mutu (Sriwidadi, Manajemen Mutu Pendidikan, 2001). Pendekatan lain dari mutu adalah "Zero Defect" atau tanpa cacat yang dikemukakan oleh Philip B. Crosby (1979) atau membuatnya benar sejak pertama kali (make it right the first time) yang dijabarkan ke dalam 14 elemen proses perbaikan mutu, yaitu: (1) Komitmen Manajemen (Management Commitment), (2) Tim Perbaikan Mutu (Quality Improvement Team), (3) Pengukuran Mutu (Quality Measurement), (4) Evaluasi Biaya Mutu (Cost of Quality Evaluation), (5) Kesadaran Mutu (Quality Awareness), (6) Tindakan Perbaikan (Corrective Action), (7) Komite Ad Hoc untuk Program Zero Defect, (8) Pelatihan Penyelia (Supervisor Training), (9) Hari Zero Defect, (10) Penentuan Sasaran (Goal Setting), (11) Penghapusan Penyebab Kesalahan ( Error Cause Removal ), (12) Penghargaan/pengakuan (Recognition), (13) Dewan Mutu (Quality Council), (14) Lakukan Berulang Kali (Do It Over Again).

Dr. Joseph M. Juran (1954) dalam bukunya Juran on Leadreship for Quality mengungkapkan Trilogi Juran sebagai berikut: (1) Perencanaan mutu, suatu proses yang mengidentifikasikan pelanggan, persyaratan pelanggan, fitur produk, serta jasa yang diharapkan pelanggan, dan proses untuk menyampaikan produk atau jasa dengan atribut yang benar dengan memberikan fasilitas untuk mentransfer pengetahuan ini kepada bagian produksi, (2) Kendali mutu, suatu proses produksi diuji dan dievaluasi terhadap persyaratan-persyaratan asalnya yang diminta oleh pelanggan. Masalah-masalah dideteksi untuk kemudian diperbaiki, (3) Peningkatan mutu, yang meliputi alokasi sumber daya, memberikan tugas kepada seseorang untuk mendorong suatu proyek, pelatihan yang digunakan untuk mendorong suatu proyek, dan membuat sutu struktur umum yang permanen untuk meningkatkan mutu dan mempertahankan yang telah dicapai. Berdasarkan ketiga pakar mutu, maka peningkatkan mutu atau kualiatas lembaga pendidikan itu melalui beberapa tahapan dan perencanaan yang matang. Lembaga pendidikan harus mengadakan pengukuran dan evaluasi diri atas kemajuan pendidikan yang dikelolanya. Evaluasi diri tersebut sebagai alat peningkatan atau perbaikan mutu pendidikan melalui instrumen komponen. Untuk itu perbaikan mutu pendidikan harus dilakukan secara berkesinambungan untuk menjawab setiap tuntutan perkembangan situasi jaman sesuai dengan cita-cita, keinginan dan kebutuhan dari pengguna yaitu masyarakat.

\section{METODE PENELITIAN}

Penelitian yang dilakukan adalah penelitian kualitatif dengan pendekatan interaktif. peneliti dapat berinteraksi secara langsung dengan subyek penelitian. Peneliti menghabiskan banyak waktu untuk memahami setting sosial di kancah penelitian. Istilah paling populer yaitu human as instrumen peneliti sebagai alat untuk mencari data dan menganalisis data yang didapatkan. Karakteristik lain penelitian kualitatif dengan pendekatan interaktif adalah peneliti juga terlibat langsung dalam penelitian. Dalam kondisi ini peneliti melakukan interaksi secara langsung dengan subyek penelitian(Musfiqon, 2012). Penelitian tentang integrasi kurikulum internasional, nasional dan madrasah di MI Muslimat NU Pucang Sidoarjo yang dijadikan subjek penelitian antara lain: kepala madrasah MI Muslimat NU Pucang Sidoarjo, wakil kepala madrasah urusan kurikulum dan kesiswaan, pendidik, tenaga kependidikan, orang tua wali murid serta peserta didik dan lulusan MI Muslimat NU Pucang Sidoarjo. Adapun objek penelitian ini integrasi kurikulum internasional, nasional dan madrasah di MI Muslimat NU Pucang Sidoarjo adalah mulai dari perencanaan, implementasi dan hasil. Tehnik pengumpulan data yang akan dilakukan dalam penelitian ini adalah wawancara, observasi, dokumentasi, catatan lapangan dan triangulasi.

Analisis data dalam penelitian kualitatif ini dihimpun dari wawancara, observasi, dokumen dan catatan lapangan berasal dari pertanyaan-pertanyaan yang dihasilkan pada proses yang paling awal dari penelitian, selama pembuatan konseptual, dan fase pertanyaan yang berfokus pada penelitian. Singkatnya analisis data dilakukan dalam dua tahapan, yaitu selama proses pengumpulan data dan pada akhir pengumpulan data. Adapun langkahlangkah analisis data penelitian kualitatif ini didasarkan pada teori Miles \& Huberman model interaktif dalam analisis data bahwa penelitian ini bersifat interaktif dimana antara satu tahapan dengan tahapan yang lain saling terkait (berinteraksi). Adapun teknik analisis data pada penelitian ini terbagi menjadi 4 yaitu: Data collection, data reduction, data display dan conclution drawing. Pengecekan keabsahan data dilakukan sampai ditemukan data yang benar-banar valid dan dapat dipertanggungjawabkan. Dari penyesuaian data melalui satu sumber yang lain serta mencari bukti otentik dari data tersebut. Untuk menjamin keabsahan data peneliti mengikuti 4 macam kriteria seperti yang dikemukakan Lincola dan Guba yaitu kredibilitas, transferabilitas, dependabilitas dan konfirmabilitas (Riyanto, 2007). 


\section{HASIL DAN PEMBAHASAN}

Berdasarkan hasil penelitian menggunakan metode wawancara, observasi, dokumentasi, catatan lapangan dan triangulasi, maka peneliti menemukan hasil penelitian. Hasil penelitian kemudian diolah kembali menggunkan teknik analisis data. Hasil analisis data ini berupa pembahasan penelitian sebagai berikut:

\section{A. Kebijakan Kepala Madrasah untuk Mencapai Tujuan Implementasi Integrasi Kurikulum Internasional, Nasional dan Madrasah di MI Muslimat NU Pucang Sidoarjo.}

Kebijakan yang diambil oleh kepala madrasah agar mencapi tujuan implementasi integrasi kurikulum internasional, nasional dan madrasah di MI Muslimat NU Pucang ini ada beberapa tahapan yang harus dilakukan. Kepala madrasah sebagai manger di sebuah lembaga pendidikan, maka juga mempunyai fungsi Planning, Organizing, Actuating dan controlling. Maka kebijakan kepala madrasah yang pertama yaitu planning( perencanaan) dimulai dengan membuat RKM ( Rencana Kerja Madrasah) jangka panjang dan jangka pendek yang didalamnya memuat delapan SNP (Standar Nasional Pendidikan) yang ada di dalam standar Isi. Pada standar proses dilakukan pengintegrasian kurikulum dengan mengadopsi kurikulum Cambridge University dengan tiga mata pelajaran Mathematic, English, dan Science yang diadaptifkan ke dalam mata pelajaran umum dari kurikulum nasional Kemendiknas dan mata pelajaran agama Qur'an Hadits, Aqidah akhlaq, Fiqih, SKI dan Bahasa Arab dari kurikulum madrasah Kemenag. Pembuatan bahan ajar yang dilakukan oleh TIM dengan cara dikelompokkan pada setiap rumpun mata pelajarannya untuk dilakukan: analisis, penyelarasan, pengkombinasian dan pengintegrasian kurikulum Cambridge, kemendikbud dan kemenag baik dalam Kompetensi Inti (KI), kompetensi dasar (KD), topik dan sub materi, maka terbentuklah bahan ajar (text book) Sedangkan bagi pendidik menyusun perangkat pembelajaran (RPP) yang terjabarkan dalam menyusun program tahunan, program semester, bulanan, dan mingguan yang terkait dalam pelaksanaan instruksional dalam bidang studi atau kelas yang menjadi tanggung jawabnya. Hal ini terjabarkan di dalam silabus dan RPP (lesson plan). Bahan ajar dan perangkat pembelajaran ini digunakan bagipara pendidik untuk mengimplementasikan integrasi kurikulum internasional, nasional dan madrasah di MI Muslimat NU Pucang Sidoarjo. Sedangkan pada standar Penilaian ada tiga jenis penilaian, yaitu (1) Penilaian oleh pendidik dalam bentuk Daily test terdiskripsi, (2) Penilaian satuan pendidikan dengan Assessment Holistic I dan I (AH1dan AH2), PAS dan PAT, (3) Penilaian hasil belajar oleh pemerintah dalam bentuk UAMNU, UN dan UAMBD. Pada Standar Kompetensi Lulusan dari MI Muslimat NU Pucang Sidoarjo dapat diterima di sekolah favorit baik Negeri maupun Swasta serta senantiasa berdzikir kepada Allah SWT dan berakhlaqul karimah yang sejalan dengan visi dan misi MI Muslimat NU Pucang Sidoarjo. Untuk standar pengelolaan, sarana prasarana, pendidik dan tenaga kependidikan dan pembiayaan juga memberikan kontribusi yang penting bagi implementasi integrasi kurikulum yang ada di MI Muslimat NU Pucang Sidoarjo ini.

Kedua, Adanya organizing yang baik oleh kepala madrasah secara struktural akan mempengaruhi dari implementasi integrasi kurikulum internasional, nasional dan madrasah di MI Muslimat NU Pucang Sidoarjo. "Organizing is the determining, grouping and arranging of the various activities needed necessary forthe attainment of the objectives, the assigning of the people to thesen activities, the providing of suitable physical factors of enviroment and the indicating of the relative authority delegated to each respectives activity (R. Terry, 2010) Dari pengertian organizing yang dikemukakan oleh R.Terry, George dan Leslie W.Rue, maka kepala madrasah dibantu oleh wakil kepala madrasah telah melakukan beberapa pembagian kerja (job discription) sesuai dengan bidangnya masing-masing. Terry mengemukakan tentang azas-azas organizing, sebagai berikut yaitu: (1) The objective (tujuan), (2). Departementation (pembagian kerja), (3) Assign the personel (penempatan tenaga kerja), (4) Authority and Responsibility (wewenang dan tanggung jawab), (5) Delegation of authority (pelimpahan wewenang). Pembagian kerja yang dilakukan oleh kepala madrasah kepada beberapa wakasek sejalan dengan teori yang dikemukakan oleh Terry. Kepala Madrasah memberikan wewenang dan tanggungjawab kepada para wakasek untuk melaksanakan tugas pokok dan fungsinya masing-masing. Kepala madrasah sebagai manajer akan menerima laporan secara berkala dari para wakaseknya.

Ketiga, pengarahan (actuating) yang dilakukan oleh kepala madrasah dalam bentuk bimbingan kepada rekan kerja baik pendidik maupun tenaga kependidikan agar bekerja secara efektif dan sesuai dengan SOP (Standar Operasional Prosedur) demi tercapainya integrasi kurikulum internasional, nasional dan madrasah di MI Muslimat NU Pucang Sidoarjo. Maka, kepala madrasah harus memilliki prinsip keteladanan, konsistensi, keterbukaan, kelembutan, dan kebijakan agar isi pengarahan yang diberikan kepada pendidik dan tenaga kependidikan dapat dilaksanakan dengan baik." Actuating is setting all members of the group to want to achieve 
and to strike to achieve the objective willingly and keeping with the managerial planning and organizing efforts (R. Terry, 2010).

Keempat, Controlling dilakukan oleh kepala madrasah sebagai tolak ukur akan keberhasilan dari implementasi integrasi kurikulum internasional, nasional dan madrasah di MI Muslimat NU Pucang Sidoarjo ini. Pengawasan yang dilakukan oleh kepala madrasah ini berupa supervisi yang sudah terprogram dengan baik."Controlling can be defined as the process of determining what is to accomplished, that is the standard, what is being accomplished. That is the performance, evaluating the performance, and if the necessary applying corrective measure so that performance takes place according to plans, that is conformity with the standard (R. Terry, 2010). Teori ini sejalan dengan yang dilakukan oleh kepala MI Muslimat NU Pucang Sidoarjo. Pengawasan Kepala madrasah dilakukan melalui pemantaun, supervisi, evaluasi, pelaporan, dan tindak lanjut. Pemantauan, supervisi, dan evaluasi dilakukan terhadap perencanaan, pelaksanaan, dan penilaian hasil pembelajaran yang dilakukan oleh seorang pendidik pada setiap jenjang kelas di MI Muslimat NU Pucang Sidoarjo. Setelah itu akan ada tindak lanjut diberikan dalam bentuk penguatan, penghargaan, teguran, dan saran mengikuti pelatihan.

\section{B. Implementasi Integrasi Kurikulum Internasional, Nasional dan Madrasah di MI Muslimat NU Pucang Sidoarjo}

Implementasi integrasi kurikulum ini melalui beberapa tahapan diantaranya: (1) Pengembangan bentuk pengolahan belajar dan kelas, (2) Pengembangan model pembelajaran, (3) Program pemngembangan diri, (4) Evaluasi.Pada tahap pengembangan bentuk pengolahan belajar MI Muslimat NU Pucang Sidoarjo bentuk madrasah ibtida'iyah yang menerapkan full day school karena jam pelajaran yang begitu padat. Dari mulai pukul 06.45-16.00 setiap dari Senin, Selasa, Rabu dan Kamis untuk Jum'at Pukul 10.45-15.00. Pada pagi hari dimulai dengan pembiasaan pagi yaitu: membaca Asmaul Husnah shalat Dhuha, Tahfidz, Istiqhosah, setelah itu Menyanyikan lagu Indonesia Raya dan Eglish day. Pada pukul 08.00- 16.00 Pembelajaran integrasi kurikulum dalam bentuk tematik dan diselingi dengan ishomah untuk shalat Dhuhur dan ditutup dengan shalat Ashar. Dengan pembagian kelas, khusus kelas enam dibagi berdasarkan tingkat kemampuan ada low. Middle dan high. Model pembelajaran pada implementasi integrasi kurikulum internasional, nasional dan madrasah menggunakan model PAIKEM, selain itu Pendidik juga merancang metode baru yang sesuai dengan kajian materi dan karakteristik peserta didik. Diantaranya yaitu Cooperatif Learning (kerjasama antar siswa dalam kelompok) bisa tipe NHT, STAD, jigsaw, demonstrasi, Contextual Teaching Learning (CTL), Pendidikan Matematika Realistik Indonesia (PMRI), observasi, ceramah, tanya jawab, penugasan. Pada implementasi pengembangan diri di MI Muslimat NU Pucang Sidoarjo dalam bentuk ektra yaitu ektrakurikuler wajib dan ektrakurikuler pilihan. Pramuka merupakan ektrakurikuler wajib yang harus diikuti oleh Peserta didik dari kelas 1 s.d. 6. Sedangkan ektrakurikuler pilihan diantaranya yaitu olimpiade Mathematic, English dan Scince, Bahasa Mandarin, Robotika, Patrol, Pagar Nusa, dan Paskibraka. Tujuan dari ektrakurikuler ini adalah untuk mengembangkan bakat dan minat peserta didik dalam bidang akademik maupun non akademik. Evaluasi dari implementasi integrasi kurikulum internasional, nasional dan madrasah dilakukan dengan menggunakan tes dan non tes, baik dalam bentuk tertulis maupun lisan, pengamatan kinerja, pengukuran sikap, penilaian hasil karya berupa tugas, proyek dan/atau produk, penggunaan portofolio dan penilaian diri. Integrasi kurikulum internasional, nasional dan madrasah di MI Muslimat NU Pucang ini sesuai dengan pengembangan kurikulum Grass Rootmodel dan Olivia model. Pendapat ini didasarkan atas pertimbangan bahwa di madrasah ini, pendidik adalah perencana, pelaksana dan juga penyempurna dari pengajaran yang ada dikelasnya.

\section{Kualitas Lulusan Integrasi Kurikulum Internasional, Nasional dan Madrasah di MI Muslimat NU Pucang Sidoarjo}

Dari penyajian data diatas maka maka kualitas lulusan sesuai dengan teori mutu dari Deming, mutu adalah apapun yang menjadi kebutuhan dan keinginan pelanggan. Telah dibuktikan dengan adanya prestasi akademik dan non akademik lulusan setelah adanya implementasi integrasi kurikulum internasional, nasional dan madrasah di MI Muslimat NU Pucang Sidoarjo. Dari bidang akdemik dibuktikan dengan dari hasil test kemampuan akademis, misalnya ulangan umum, UAMBD atau US. Berdasarkan penyebaran lulusan peserta didik banyak yang diterima di SMP atau MTS yang favorit sesuai dengan keinginan peserta didik dan dapat dibuktikan dengan hasil Ujian Akhir peserta didik Ceck Point, SKHUN dan UAMBD. 
Berdasarkan teori mutu dari Edwrd Deming maka MI Muslimat NU Pucang Sidoarjo dengan mengimplementasikan integrasi kurikulum dengan pengadopsian tiga mata pelajaran Mathematic, English dan Science kurikulum Cambridge University, dan mengadaptifkan mata pelajaran umum kurikulum nasional dari Kemendikbud serta mata pelajaran agama Qur'an Hadits, Aqidah Akhlak, Fiqih, SKI, Bahasa Arab kurikulum madrasah dari kemenag menghasilkan kualitas lulusan atau output yang sesuai dengan kebutuhan masyarakat. Hal ini terbukti bahwa lulusan MI Muslimat NU Pucang Sidoarjo dapat membaca dan menghafal Al-qur'an dengan baik, terbiasa berperilaku Islami dalam kehidupan sehari-hari dan dapat diterima di SMP/MTS yang favorit.

\section{KESIMPULAN}

Peneliti menitikberatkan pada proses perencanaan, implementasi dan hasil dari integrasi kurikulum internasional, nasional dan madrasah di MI Muslimat NU Pucang Sidoarjo. Penelitian ini mengekplorasi integrasi kurikulum internasional, nasional dan madrasah sesuai dengan kebutuhan masyarakat bahwasannya setelah implementasi integrasi kurikulum internasional, nasional dan madrasah di MI Muslimat NU Pucang Sidoarjo, lulusannya mampu membaca dan menghafal Al-qur'an dengan baik, terbiasa berperilaku Islami dalam kehidupan sehari-hari dan dapat diterima di SMP/MTS yang favorit.

\section{UCAPAN TERIMA KASIH}

Merupakan kebahagiaan dan kebanggaan tersendiri bagi penulis melalui perjalanan studi dan bisa menyelesaikan karya ilmiah. Oleh karena itu, dalam kesempatan ini penulis ingin mengucapkan terima kasih serta penghargaan setinggi-tingginya kepada pihak-pihak yang mendukung terselesaikannya karya ilmiah ini kepada kepala madrasah MI Muslimat NU Pucang Sidoarjo serta para pendidik yang telah berkenan memberikan izin kepada penulis untuk melakukan penelitian dan membantu memberikan data yang dibutuhkan selama penelitian. Semoga Allah membalas semua jasa-jasa kebaikan semuanya.

\section{REFERENSI}

1. Al Barry, M. Dahlan. 2001. Kamus Modern Bahasa Indonesia. Yogyakarta : Arloka.

2. Herry, Hermawan Asep. 2011. Pengembangan Kurikulum dan Pemebelajaran. Jakarta: Universitas Terbuka Muhajirin. 2007. Pengembangan Kurikulum Pendidikan Agam Islam di Sekolah Madrasah dan Perguruan Tinggi. Jakarta: PT Raja Grafindo Persada.

3. Mulyana Mulyasa. 2006. Kurikulum Tingkat SatuanPendidikan, Suatu Panduan Praktis. Bandung: PT Remaja Rosdakarya

4. Musfiqon, M. 2012. Panduan Lengkap Metodologi Penelitian Pendidikan. Jakarta: Prestasi Pustaka.

5. Riyanto, Y. 2007. Metodologi Penelitian Pendidikan Kualitatif dan Kuantitatif. Surabaya: UNESA Press.

6. Shihab, Quraish. 1999. Membumikan Al-Quran. Bandung : Mizan.

7. Sriwidadi, Teguh. 2001. Manajemen Mutu Pendidikan. The Winners.

8. Subandijah. 1996. Pengembangan dan Inovasi Kurikulum. Jakarta : PT Raja Grafindo Persada.

9. Subiyantoro, Andi Septilinda Susiyani. 2017. Manajemen Boarding School dan Relevansinya dengan Tujuan Pendidikan Islam di Muhammadiyah Boarding School (MBS) Yogyakarta. Jurnal Pendidikan Madrasah

10. Supriyanto, E. 2009. Inovasi Pendidikan, Isu-Isu Baru Pembelajaran, Manajemen dan Pendidikan.

11. Surakarta: Muhammadiyah University Press.

12. Terry R., George dan Leslie W.Rue. 2010. Dasar-Dasar Manajemen. Jakarta: Bumi Aksara.

13. Yamit, Zulian. 2001. Manajemen Kualitas: Produk dan Jasa. Yogyakarta: Ekonisia. 